MichU

CenRED $R$

37
CENTER FOR RESEARCH ON ECONOMIC DEVELOPMENT

THE UNIVERSITY OF MICHIGAN

\title{
Pragmatism and the Primary School The Case of a Non-Rural Village
}

\author{
by \\ JOYGE LEWINGER MOOCK
}

CRED Reprints

(New Series)

No. 37

Center for Research on Economic Development

University of Michigan

Ann Arbor, Michigan 48108 


\section{Center for Research on Economic Development CRED Reprints}

No. 27. "The Rediscovery of Exports by the Third World" by Richard C. Porter and Charles P. Staelin. (Foreign Trade Review, January-March 1972, pp. 523-539)

"No. 28. "Budget Policy and Economic Stability in Postwar Japan" by Wayne Snyder and Tsutomu Tanaka. (International Economic Review, Vol. 13, No. 1, February 1972, pp. 85-110)

No. 29. "The Cost of Tying Aid: A Method and Some Colombian Estimates" by Thomas L. Hutcheson and Richard C. Porter. (Princeton Studies in International Finance, No. 30, March 1972, 53 pp.)

No. 30. "The Development Process" by O. Aboyade, and "Comments on Professor Aboyade's Paper" by Wolfgang F. Stolper. (Reconstruction and Development in Nigeria edited by A. A. Ayida and H. M. A. Onitiri. Published by the Nigerian Institute of Social and Economic Research, 1971, pp. 34-80)

No. 31. "Comments on Gustav Ranis' 'Relative Prices in Planning for Economic Development" by Peter Eckstein and Wolfgang F. Stolper. (International Comparisons of Prices and Output edited by D. J. Daly. Published by National Bureau of Economic Research, 1972, pp. 306-325)

No. 32. "The Effects of Tax Exemption on Investment by Industrial Firms in Colombia" by Richard E. Billsborrow and Richard C. Porter (Weltwirtschaftliches Archiv, Vol. 108, No. 3, 1972, pp. $396-426)$

No. 33. "Comment on the Role of Monetary Institutions" by Wolfgang F. Stolper. (Africa and Monetary Institutions edited by Rodrigue Tremblay. Published by Holt, Rinehart et Winston, Montreal, 1973, pp. 101-108)

No. 34. "Internal Effects of Devaluation" by Wolfgang F. Stolper. (Africa and Monetary Institutions edited by Rodrigue Tremblay. Published by Holt, Rinehart et Winston, Montreal, 1973, pp. 411419)

\footnotetext{
* not available
} 



\title{
PRAGMATISM AND THE PRIMARY SCHOOL: THE CASE OF A NON-RURAL VILLAGEI
}

\author{
JOYCE LEWINGER MOOCK
}

\section{INTRODUCTION}

$\mathrm{T}$ HE aim of this paper is to analyse the educational needs of one small community in Kenya in terms of its changing socio-economic patterns, and to show how attitudes towards the school system have their roots within this setting. The data are drawn from a nineteen-month study in South Maragoli Location of Kakamega District, Western Province. As part of a larger study concerning the effects of labour migration upon agricultural enterprise, a tracer project was conducted on I 39 Standard VII leavers from three primary schools, situated within a one-mile radius, to learn the leaver's employment expectations, his family background, the network connections by which he enters into the labour market, and finally the way in which the community interprets and manipulates the school system to suit its particular needs. The statistical data presented have so far emerged from the school study and from a larger sub-location sample of I 59 households. While several questionnaires, intended as cross-checks were administered to students and parents, the qualitative material results from an intensive study utilizing anthropological field techniques in the schools' constituent villages.

\section{The SetTing}

Several factors have combined in recent years to make Maragoli one of the greatest 'problem' areas for economic development in Kenya. The single most outstanding characteristic of Maragoli is in its population density, estimated in 1969 at approximately $\mathrm{I}, 500$ persons per square mile. The location consists of 35.5 square miles divided into farm units averaging two to three acres and six household members. Although there has been some Maragoli migration into surrounding locations, these lands are almost as densely populated, and the understandable territorial protectiveness of other Abaluhyia sub-tribes and of Nandi and Luo neighbours discourages expansion.

Maragoli is situated fifteen miles north of the port town of Kisumu. There is a good network of roads to Kisumu and other major towns in Kenya. This factor, together with adequate rainfall, available cash crops, and the possibility of developing internal markets, gives Maragoli a high potential for agricultural development. However, population pressure on the land had long ago created many uneconomic farm units. For the vast majority of farmers, improvements in farm technology might give them at best self-sufficiency in maize and beans-the area's stable foods-which are now partially imported.

The Maragoli response to their worsening agricultural situation has been to

I An earlier version of this article appeared as Discussion Paper No. I35, Institute for Development Studies, University of Nairobi, March 1972. David Court, Walter Elkan, Peter Moock, and Mary Kempe of the Institute made many useful sug- gestions. I wish to thank them and also my research assistant, Thomas Susu, for the time contributed to this project. Finally, appreciation is due to William Dalton and Wolfgang Stopler for suggestions leading to the revision of the paper for publication. 
remove as many persons from the land as possible. Since the beginning of this century labour migration to the major towns and to the large farming estates of East Africa has acted as a safety valve for the overcrowded conditions on the land. Today, in at least one Maragoli sub-location, 67 per cent of the adult males between 20 and 60 years of age work, or are in search of work, outside Kakamega District at any given time. Furthermore, the 1969 census shows a 100:146 ratio of men to women in the 25 to 49 age group in the district as a whole. Maragoli, in a sense, has become a 'bedroom community' in which a land-starved population, dominated by women and children, is dependent upon remittances from outside to pay expenses at home.

For many years the farms of Maragoli have offered no opportunity for the majority of the young. In fact, their remaining on the land is often a great disservice to their families. Around the turn of the century, when missionaries were settling into the area, pressure on the land was exacerbated by several famines, rising consumer expectations, and the introduction of taxation. Therefore, the Maragoli welcomed educational programmes introduced by the missionaries, which expanded opportunities for wage employment, with much greater enthusiasm than their neighbours. References in the archives of the Kaimosi Friends' Mission indicate the early pragmatism of the Maragoli in their outlook towards education, and their constant pressure upon the mission to expand its educational activities. For example, by 1914, 2,662 students were enrolled in Maragoli schools-an outstanding number in the whole of East Africa at that time.

From the start, the ecological conditions of the area determined the orientation of the school in removing youngsters from the land. However, the desire for wage income was not accompanied by alienation from the local environment. Many successful students were rewarded with wage employment as teachers, evangelists, or government functionaries; and these high-status persons, whose skills were in demand all over Kenya, preferred to remain within their own district. In addition, most migrants in the early years were 'target income workers' who accepted sixmonth labour contracts to meet their monetary needs. They then returned home for several months until wage employment was required once more. Outside employment, from its inception, has been a necessity for most Maragoli rather than a choice.

The tradition of labour migration is further strengthened by an ever-increasing bridewealth, which usually necessitates late marriage. Most Maragoli men do not, therefore, control land or labour until they are middle-aged. Descent is recognized in the agnatic line, and inheritance of property and possessions is patrilineal and ideally distributed equally between sons. However, the eldest son has an advantage over his brothers in his prior claim for bridewealth cattle, his right to the first share of land, and his executor powers over the estate, jointly with his mother, should the father die while some of his sons are too young to receive their inheritance. The youngest brother is also favoured in his rights to the land which the father has reserved for himself in his old age. But whatever their sibling position, few sons receive land before marriage or the birth of children. In addition, the recent programme of land registration in the Location strengthens the father's control over farm fragmentation and weakens the claims of unfavoured dependents. One probable effect of this programme will be that a high percentage of young men are forced off the land permanently. 
Although inheritance has been restricted traditionally to males, changing economic patterns in Maragoli, including the sale of land and the labour migration of men, have given new rights to women in the control of farm resources. Recent land cases in the Location show that daughters can now inherit omulimi gwagulwa (purchased land), as opposed to omulimi gwaguga (ancestral land) which is passed down through the agnatic line, if they are without brothers or if they are favoured by the father. Furthermore, as the growing dependency upon a cash economy and the increasing population pressure on the land make obligations to a large extended family more difficult to fulfil, many uninherited widows take a central role in the division of their husband's land and in decisions concerning paid labour and cash crops. The position of women in the community is further strengthened by their independent (though tiny) incomes, by their control over children, and by the leadership roles they have assumed in local politics, church, and school since their men have been away. These new roles are reflected in mothers' attitudes towards the school and in girls' expectations for the future.

Freedom from farm labour also has direct bearing upon the Maragoli school system. The basic domestic group in Maragoli is the elementary family, sometimes extended to include an aged parent, a daughter-in-law, or a niece or nephew. It is mainly within this unit that household and farming duties are distributed, and food and income shared. However, most families have diverse sources of income. Women generally have independent part-time occupations as local traders, potmakers, or members of hired labour groups. Many 'underemployed' men brew beer, trade in cattle, have specialized skills, or own small shops. School children often take jobs when school is not in session in order to earn pocket money. These varied sources of income, as well as small farm sizes and a non-rigid division of labour between sexes and ages, lessen the family's dependence upon the labour of each of its members. Thus, the adolescent can be released from farm duties with little financial loss to the family. During those late rainy seasons in which heavy farm labour requirements overlap with school terms, students are generally replaced on the farm by hired labour. This release from farm duties allows students a long career in attending school.

Kinship obligations within the extended family further encourage school attendance. Many of the traditional responsibilities for aiding relatives and the rights to benefit from the economic position of extended kin can no longer be fulfilled in a situation where resources are extremely limited and status is acquired more by the accumulation of wealth, than by its distribution. Yet the extended family and clan group still play important roles in Maragoli's social organization. One such role which bears directly upon the educational system is the accommodation which town relatives provide to school leavers in search of employment or secondary-school places. Since the network of almost every Maragoli family extends into the major towns of Kenya, the mobility of youngsters seeking jobs and school places is greatly facilitated.

Those, however, who are unable to continue their education or find employment have great difficulty in earning a decent income on their own. For wage employment and entrepreneurial activity at home are closely connected. Cash-crop or dairy farming requires an initial financial investment of substantial size. Usually the farmer must 
purchase land to add to his inherited plot before he can have the minimal acreage required for any cash enterprise. Land in Maragoli, because of its social security value, usually sells at over shs. 4,000 an acre, and a plot on a settlement scheme is difficult to acquire. But even if the farmer overcomes his land constraint, he still needs money for such agricultural inputs as seed, fertilizer, equipment, labour, or animals. Therefore, most progressive farmers in Maragoli are persons who have returned from several years of wage employment outside, or who have non-farming occupations within, the home area.

The same financial outlay is required to become a full-time craftsman. As previously mentioned, Maragoli has a plentiful supply of semi-skilled, part-time craftsmen. However, these local fundis, with simple training and insufficient equipment, cannot earn a living to support their families. Aspiring full-time entrepreneurs need not only high-quality training to make themselves outstanding in a sea of craftsmen, and to satisfy the town-bred standards of the community, but also money to buy equipment, trade licences, and shop facilities to meet health regulations. Most important, they require land and labour of their own in order to lessen profit-draining obligations to parents and relatives on whom they would otherwise depend. Too often these socioeconomic constraints on youngsters are forgotten in the designs of vocational programmes which historically have been aimed at 'elementary skills' in the 'pastoral rural' areas.

Money flows into Maragoli in the form of remittances, which can be spent on agricultural products and on consumer goods and services. Yet few youngsters straight out of school can take advantage of the opportunities for full-time local self-employment. Furthermore, as opportunities for wage employment in towns steadily decline, there will be a drop in the percentage of middle-aged persons with capital to finance entrepreneurial enterprises at home.

Although Maragoli is located 250 miles from Nairobi and has no town centre of its own, it cannot be classified as a 'rural' or 'agricultural' area. Instead, it might be more appropriate to think of Maragoli with its dense population, two- to three-acre family plots, spread of social services, and dependency upon town income, as a dislocated Nairobi suburb. Furthermore, the constant flow of men and money between town and Location functions to articulate the community into the mainstream of contemporary Kenyan life.

\section{Parental Attitudes Towards Education}

Given the situation in which the land can no longer offer opportunities to the young, Maragoli parents have turned to the school as the only alternative at hand which might provide their children with a satisfactory future. From the time that the school system was introduced into the area, parents have viewed education as an instrument for removing youngsters from the land. Of the fathers of the $\mathrm{r} 39$ students in the tracer group, only ro per cent own more than five acres of farmland, while 65 per cent own less than three acres. Since the fathers of the eighty-six boys in the sample have an average of four sons each, only seven boys can expect to be given at least two acres of land-the figure that has been suggested by the Ministry of Agriculture as the minimum viable acreage for a farm in Maragoli.

Many fathers view education as a substitute for the land which they cannot give 
their sons. It is hoped that education will lead to employment which will enable offspring to purchase their own farms. Furthermore, fathers feel that a wage-earning child is responsible for the welfare and school fees of his siblings, and also for the care of his mother, especially if the father has more than one wife. Out of the tracer group, 44 students who were attending school in $197 \mathrm{I}$ had at least one employed older brother. Of these, 30 ( 68 per cent) had their school fees paid by siblings. In the I4 remaining cases the fathers paid the fees, and in ro of these their salaries were far larger than those of their employed sons.

Women, with their greater participation in community affairs, provide a major thrust behind educational expansion. With husbands working outside for a good part of their adult lives, women have come to rely more upon their children for support. Most working men send home monthly remittances. But with a lack of job security in towns, especially in the domestic work in which middle-aged Maragoli men specialize, women must depend upon more than one income for household expenses. Also, with the decline in frequency of widow inheritance, sons have come to take over their uncle's responsibility in caring for their mother in her old age. Although some men spoke of school fees as a deterrent to having large families, younger women seem to be bearing a slightly higher number of children in a shorter period of time than did their seniors. This increased dependence upon children reflects parental feelings that welfare and social security are lacking, and leads to a situation in which parents try to hedge their bet that education will pay off by putting many children into the school system for as long as possible. Many wives, in fact, co-ordinate visits to town with the beginning of school terms so that they can carry back the fees in person.

Parents have come to rely upon daughters as well as sons for support. Apart from job opportunities for girls, a daughter with a Std. VII education can now bring well over shs. I,000 and five cows in bridewealth and, perhaps more important, conjugal ties with a well-to-do family. Although girls have always lagged behind boys in primary-school attendance, the situation is rapidly changing as a result of socioeconomic patterns and resultant parental attitudes towards the education of daughters. 1971 Location statistics show a 2:3 ratio of girls to boys at the Std. VII level, and educational reports for Kakamega District over the past few years indicate that the enrolment of girls in primary schools is rapidly catching up with that of boys.

Enrolment inflation, particularly in the lower standards, is further encouraged by parental feelings that there should be equality between sons in their access to education. Although this is the ideal, advantage in sibling position occurs in education as well as in property inheritance. The eldest son has first claim on parental savings for school fees. Often his siblings have late starts entering Std. I or are held back in the lower primary grades where fees are less expensive, until the father can replenish his finances or until the elder child can pass through the system. Once the eldest son is earning an income, the last born is more likely to have a new source of finance upon which to rely for his fees.

Because parents feel dependent upon their offspring, and therefore want children to have the education which will lead to employment, the first priority for whatever funds parents are able to accumulate is school fees. Although recent experiments in Maragoli (P. Moock, I97I) have shown that hybrid seed, fertilizer, a sufficient labour 
force, and good husbandry can more than double most current maize yields, farmers complain that they cannot find the few hundred shillings with which to make this investment in their land. Furthermore, they are forced to sell a large proportion of what maize they do grow directly after harvest, when prices are at their lowest, in order to pay school fees. For many years cash-crop farming in Maragoli has been viewed only as a supplement to wage income. Even at nearby Chavakali Secondary School, which has a long-established agricultural training programme, the majority of Maragoli graduates enter non-agricultural employment out of necessity. While competition for jobs grows more keen, parents are tying up their money in an academic school system at the expense of other development enterprises at home.

The idea that education paves the way for wage employment is strongly imprinted upon the community. It is viewed as a historical factor exemplified by the middle-aged residents themselves. Teachers, in particular, are often singled out as examples of the benefits of education. Most middle-aged teachers hold leadership positions in areas of community life outside the school. As the early products of a mission education and having long familiarity with government operation, they play leading roles in church and local political affairs. Also, their steady but low salaries have both enabled and forced them to seize local entrepreneurial opportunities for supplementing their income. It is mainly these men who are the shopkeepers, mill owners, and progressive farmers in Maragoli. When household heads in the sub-location study were asked to name six persons in the community whom they most respected, 40 per cent (the largest single percentage) mentioned people who were teachers. Thus, one might suspect that children are forming attitudes about education not from the material that is being taught, but from the teacher's physical presence in the classroom as a respected income earner.

The long tradition of education and wage employment in Maragoli is also revealed in the backgrounds of the parents.

TABLE I

Father's occupation by level of education attained

\begin{tabular}{|c|c|c|c|c|}
\hline \multirow[t]{2}{*}{ Occupation } & \multicolumn{4}{|c|}{ Level of education } \\
\hline & No educ. & Std. I-IV & Std. V-VIII & Higher educ. \\
\hline $\begin{array}{l}\text { Clerical/professional } \\
\text { Skilled } \\
\text { Unskilled } \\
\text { Jobless/farmer }\end{array}$ & $\begin{array}{l}\cdots \\
22 \% \\
78 \%\end{array}$ & $\begin{array}{r}9 \% \\
51 \% \\
40 \%\end{array}$ & $\begin{array}{l}31 \% \\
36 \% \\
22 \% \\
11 \%\end{array}$ & $\begin{array}{l}100 \% \\
\cdots \\
\cdots \\
\cdots\end{array}$ \\
\hline & $100 \%(9)$ & $100 \%(72)$ & $100 \%(36)$ & $\begin{array}{l}100 \%(13)={ }_{130} \\
\text { unknown }\end{array}$ \\
\hline
\end{tabular}

Those fathers who have been able to educate their children up through primary school realize first hand the economic benefits of education. Like the teachers, the parents exemplify why students should remain in the school system for as long as possible. 
When parents were questioned as to what they would like their children to do after finishing primary school, only is per cent specifically mentioned secondary education. Further discussion with the remaining parents revealed that they also preferred secondary education. However, since education is viewed as an instrument for obtaining employment, and since secondary education is no longer a guarantee of that employment, they appear ready to accept any educational programme that would lead their children to jobs.

The parents had more difficulty in answering questions about occupational preferences for their children. Although there was some bias towards clerical occupations for boys and nursing for girls, parents repeatedly stated that choice of occupation was the child's prerogative. Apparently there is little parental pressure on job choice, thus allowing students adaptive flexibility to the labour market.

Many Maragoli parents have worked or lived in Kenya towns for a large part of their lives. They have been involved in the employment scramble themselves and have been besieged by friends and family for jobs and accommodation. Thus, parents are well aware of the employment problems in the country. They express the view that town life is expensive and unattractive in comparison with life in Maragoli, and the vast majority of labour migrants claim that they would accept a lower salary if they could be employed at home. Although relatives still provide accommodation for visitors to town, they are generally unable to find them jobs; 68 per cent of the parents questioned as to who could find their children jobs in Kenya, answered 'no one'.

In this peri-urban area, dependent upon non-agricultural income, Maragoli parents look to the school as the only channel through which their children can gain employment. Education, therefore, acts as the medium by which many obligations within the elementary family can be fulfilled. Parental pressure on students is aimed at the achievement of any employment which will provide them with decent futures and enable them to meet their family responsibilities. The desperation with which parents look to the school to solve their difficulties grows out of the historical and socioeconomic setting of the area, and is reinforced by the personal backgrounds of the community members themselves.

\section{The Operation of the Primary School}

Parental attitudes towards education have had two major effects upon the school system. First, parents have deliberately forced the schools prepare their children for employment. Within the context of the Maragoli setting, this means academic education for non-agricultural paid occupations. Second, in their enthusiasm to send as many children to school for as long as possible, parents have unwittingly slowed down the education system and lowered the standard of teaching. The two effects are closely interrelated.

Before responsibility for primary education was taken away from local government in 1970, the Kakamega County Council, in response to community pressure, spent over 80 per cent of its budget on education. This percentage exceeded that of any other county council in Kenya, and in addition, Kakamega spent more money in absolute terms than any other district on teachers' salaries.

The District is well endowed with 462 primary schools, 42 of which are situated 
within South Maragoli's 35.5 square miles. However, Kakamega's 24 aided secondary schools (20 for boys and 4 for girls) provided only I 2 per cent of the District's I 3,068 Std. VII students with an opportunity for continuing academic studies. Feeling the pressure of this bottle-neck situation, parents have responded with a major effort to expand educational opportunities without the aid of government. Contributing time and money, they constructed 32 self-help 'Harambee' secondary schools in the District with locally paid management and staff. South Maragoli currently has four such schools, as well as one private high school.

Parents spend a very high percentage of their income on education. Besides school fees there are activity fees, building funds, school uniform expenses, watchmen's salaries, lunch programmes, and self-help construction and maintenance contributions. Yet despite this restricting expense, 73 per cent of children aged 8 to 16 within the sub-location study were attending primary classes, and 33 per cent of those aged 4 to 7 were in primary or nursery school. While the percentage of children who reach Std. VII is much lower than this, the proportion with some exposure to the school system is much higher. My sample was taken during the third term, when there are fewer children attending classes than in the first term. Maragoli school statistics reveal that in $1969,1,464$ children dropped out of school between terms one and two because their parents did not pay fees. This attendance drop out is most prominent in Stds. I and II. Since parents feel that children should have equal access to education, they send as many children as possible to school in the first term, especially in the lower standards where fees are less expensive. Thus, many children spend several years moving in and out of the lower standards, marking time until their elder siblings complete their education.

A more serious blockage occurs in the upper standards as a result of manipulated repeating patterns for the Certificate of Primary Education examination. Although the spread of Harambee secondary schools has helped to ease the ratio of Std. VII to Form I places, enrolment in those institutions is relatively small. Most Harambee schools operate one stream, have classes only up to Form II, employ an unqualified staff, and charge higher fees than the aided schools. Parents, therefore, still prefer to have their children repeat Std. VII until they can raise their grades on the C.P.E. examination to an acceptable level for entrance to an aided school.

Since the Government has placed a limit on the quantity and grade quality of children who may repeat Std. VII, parents and headmasters have had to work out a series of under-cover techniques in the promotion and registration systems in order to make the proportion of repeaters appear smaller. When students and school staff were questioned about repeating, the response was that only a very small number were involved in the process-less than 20 per cent. Only after a study of old registration books for the three neighbourhood schools, and after discussion with parents and their neighbours, did a new picture of the repeating phenomenon appear. Of the I 39 students in the tracer group, 58 per cent had repeated Std. VII, 78 per cent had repeated one grade in their school career, and 27 per cent had repeated at least two grades. Yet very little of this information can be found in the books for any one year or in the books of any one school.

There are a number of ways in which the repeating process operates in Maragoli. On paper, I9 schools within the Location appear to have an under-enrolment of 
students in Std. VII. In the majority of cases these figures are deceptive. Students registered for Std. VI or not registered at all are found in Std. VII classrooms studying for the following year's examination. Second, 42 per cent of the Std. VII repeaters changed schools for the following year's attendance. Although headmasters may be unaware that a newcomer is a repeater, the informal exchange patterns between neighbourhood schools are well established and can be charted if registration books from three or four local schools for several years are studied at one time. Third, the majority of repeaters remaining at their own schools change their names at registration, usually between their last names and those of their fathers.

Repeating is reinforced by the success which second- or third-timers achieve on the C.P.E. examination in comparison with fresh candidates. Out of the top twentysix scores for the three schools for the 1970 examination, 69 per cent were those of repeaters. Furthermore, repeaters made up $7 \mathrm{I}$ per cent of those students from these schools accepted for aided Form I places. ${ }^{2}$

This pattern of repeating in Std. VII causes a chain reaction of repeating down through the lower standards. However, the backlogging pressure on the school system is somewhat reduced by the enrolment attrition between Stds. IV and V. Mainly due to the jump in school fees from shs. 60 to 90 between these standards, 635 parents in Maragoli in 1970 decided to stop their children at this level. On the other hand, Maragoli parents reacted strongly against the $197 \mathrm{I}$ attempt to level the fees for all standards at shs. 70 .

The general belief that primary school leavers are too young for vocational training and land resettlement (Sheffield, 1967:24) does not seem to apply to Maragoli. Since so many children repeat classes, the age of primary-school leavers is higher than students aspiring to secondary school and their headmasters are willing to admit. When questioned about their date of birth, 67 per cent of the 139 students lowered their ages. From their answers, boys and girls averaged is years of age. However, an investigation of family background showed that in reality Std. VII boys and girls averaged 17 years of age. Out of all the students, only 19 per cent were under age 16. This long career which students spend in primary school is permitted by the lack of emphasis parents place upon agricultural production, and explains the constraints that many farmers have in cultivating their fields.

The pattern of repeating throughout the school system results in an overlap of ages in each grade. For example, one Std. VI class contained 'children' from i I to 22 years of age, while I3-year-olds within the sub-location were found in Stds. I through VII. Such age mixtures interfere with sports, discipline, and the teaching of any subject on the syllabus.

The orientation of the entire school system is focused upon the final examination. Before C.P.E. takes place, the community holds church meetings to pray for the academic success of the students. This ceremony gives some indication of the tremendous parental pressure behind classroom preparation for the examination. Teaching is done mainly through rote-memory techniques, and non-examination subjects receive little attention. The school garden usually has the worst-looking

2 The percentages given throughout this paper are based on a small sample size. They are presented within the context of one small community and may therefore be inaccurate if applied to a much larger area. For additional information on the general repeater problem in Kenya see King, 1972. 
maize crop in the village. Furthermore, Std. VII students fill out a preference list of secondary schools before taking the examination. This is the only placement service offered to school leavers. If they do not obtain a place at one of these schools, irrespective of their grades and aspirations, they feel that they have been marked as failures.

With so much invested in their children's education, and such a large reward if that education pays off, parents pay close attention to the activities of the school. Parents' meetings are usually among the best-attended activities in Maragoli and politicians campaign on platforms to expand secondary school facilities. Parental desire to send as many children to school as possible, and to keep them there until they achieve entry into an aided secondary school slows down the system, blocks the implementation of an 'environmentally biased' curriculum, and makes the teaching of any subject difficult. Although parents seem willing to send their children for vocational training, such courses are difficult to find, expensive, and offer no guarantee of a job. Until this situation changes parental pressure will keep the Maragoli school system focused upon secondary school preparation.

\section{Expectations AND Experiences of THE School Leavers}

How are the expectations, perceptions, and experiences of the school leavers themselves affected by the orientation of the school system and by the socio-economic setting of the community?

TABLE II

Post-C.P.E. activities by sex

\begin{tabular}{lccc}
\hline Activities & Boys & Girls & Total \\
\hline Aided secondary schools & $8 \%$ & $\ldots$ & $5 \%$ \\
Unaided secondary schools & 16 & $25 \%$ & 19 \\
Vocational training & 7 & 2 & 5 \\
Repeating & 51 & 47 & 50 \\
Home & I5 & 26 & 19 \\
Employed & 2 & $\ldots$ & 2 \\
\hline & $99 \%$ & I00\% & $100 \%$ \\
& $n=86$ & $n=53$ & $n=139$ \\
\hline
\end{tabular}

Table II refers to school leavers' activities one year after they took the C.P.E. examination. The table indicates that 74 per cent of all leavers remained within the academic school system, although only 24 per cent had done so by advancing to secondary school. Despite the slight chances girls have for entry into an aided secondary school, the construction of Harambee schools and the availability of private schools in towns allowed 25 per cent of the girls to advance their academic studies. Of the 27 students who attended unaided schools, 19 were at private institutions, 18 of which are located outside the Province. Thus, 53 per cent of all students who obtained a Form I place did so outside Western Province. These places were found, in all cases, with the aid of kinsmen employed in the towns in which the schools are located. The high cost of attendance at these private schools was partially alleviated by the free accommodation offered to the students by relatives. 
Only seven students entered vocational training programmes of some sort: $I$ in an aided technical school, 4 in private schools, 2 as apprentices to Asian garage mechanics. Vocational training was as an obvious second choice for 6 of these students who had previously repeated Std. VII. Of the boys who remained at home, none had farms of their own or had undertaken any full-time entrepreneurial activity.

TABLE III

Post-C.P.E. activities by C.P.E. scores

\begin{tabular}{lcccccc}
\hline Activities & \multicolumn{2}{l}{ Scores } & & & & \\
\cline { 2 - 7 } & $0-9$ & 10-14 & 15-19 & $20-4$ & $25-9$ & $30+$ \\
\hline Aided secondary school &. &. &. &.. & $60 \%$ & $100 \%$ \\
Unaided secondary school & $9 \%$ & $21 \%$ & $26 \%$ & $33 \%$ &. &. \\
Vocational training & 9 & 3 & 2 & 7 & 10 &. \\
Repeating & 61 & 50 & 55 & 40 & 10 &.. \\
Home & 18 & 26 & 14 & 20 & 20 &.. \\
Employed & 3 &. & 2 &.. &. &.. \\
\hline & $100 \%$ & $100 \%$ & $99 \%$ & $100 \%$ & $100 \%$ & $100 \%$ \\
& $n=33$ & $n=38$ & $n=42$ & $n=15$ & $n=10$ & $n=1$ \\
\hline
\end{tabular}

Table III shows that I I students with scores lower than Is points found places in unaided secondary schools, while I I students with scores above is points remained at home. Entry into unaided secondary schools seems more a function of parental status than students' scores. A sharp contrast in family background emerged when the group of twenty-seven students who attended unaided secondary schools was compared with the group of 27 leavers who remained at home. In the first group, only five fathers had less than two acres of land, and 74 per cent of the families grew cash crops. In addition, eleven fathers earned over shs. 500 per month. In the eight cases of fathers who were farmers or deceased, secondary-school fees were paid by the students' employed elder brothers. In contrast, twenty-one fathers of the second group had less than two acres of land, and only 24 per cent grew cash crops. Two fathers earned over shs. 500 per month. In the sixteen cases of fathers who were farmers, jobless, or deceased, only four school leavers had elder employed siblings.

Extended family financial obligations are lessening in Maragoli, and school fees have become almost entirely a nuclear family affair. If secondary-school education, requiring high fees, remains the major channel for earning a steady income, access to social mobility within the community is bound to lessen.

Students, themselves, are realizing the difficulties of entry into an aided secondary school. Only 57 per cent of the 139 students ( 60 per cent of the boys and 5 I per cent of the girls) anticipated obtaining a Form I place at an aided school. This percentage indicates a substantial decline in secondary-school expectations when matched with comparable figures for 1966 (Koff, I967: 408). Meanwhile, I7 per cent looked forward to unaided secondary schools and 25 per cent set their expectations upon a vocational training programme. Only I per cent anticipated direct employment. These attitudes are in line with those of the parents, reflecting a situation in which the opportunity for entry into an aided secondary school is low and does not ensure 
employment. Many students seem prepared to accept any type of further education which might lead to jobs. But until adaptive training programmes become available, they have little choice but to cling to the academic school system.

When students were asked to state their occupational preferences for jobs available to Std. VII leavers, and give reasons for their choices, 42 per cent of the boys chose occupations on the basis of availability rather than personal benefit. Only ten boys chose jobs such as teachers and clerks which today would be nearly impossible for a Std. VII leaver to obtain and only two chose a job which could not be performed locally. The major job preferences, including mechanic, carpenter, and driver are not new, as previous studies have indicated (Anderson, 1968; Heijnen, 1967). They are all jobs which can be performed outside towns, and apart from choices such as police, railway, and teacher, can be initiated on a self-employment basis.

Stated reasons for job selection which can be classified under the heading 'job availability' included opportunities for getting work, self-employment possibilities, and short training periods. Within this category, these are a few representative completions to the sentence, 'I would like to do this job because ...'

... a Standard VII pupil has no good English to speak but a mechanic can use Kiswahili or simple English.

... in my village there isn't anyone who is a mechanic.

... anyone can do this job of carpenter, even if you don't go to school.

... when you are a mechanic, if a car has damage, you can get a private job by yourself.

These types of answers indicate an awareness of the employment situation in Kenya and a willingness to channel efforts in the avenues open for employment. Girls, on the other hand, seemed more concerned with the benefits from working as nurses and secretaries rather than the availability of jobs. Although new employment roles have opened to them, girls are not under as severe pressure as boys to fulfil them.

When students were asked 'Where will you go to find work?', 28 per cent of the boys and 24 per cent of the girls expected to search for employment within a twentyfive-mile radius of their home (Vihiga, Kakamega, Kisumu). All except eleven students who expected to be away from home planned to head in the direction of employed kinsmen. Labour migration out of Maragoli takes the form of a chain of links to kinsmen who might provide accommodation and hospitality to job-seekers, even if they cannot aid with employment. Thus, Maragoli school leavers fan out in the search for employment to many small towns across the country, rather than just head for the bright lights of Nairobi.

Eighty per cent of the students viewed higher education and contacts with employed friends and relatives as the best combination for finding jobs in Kenya. However, when students were asked to complete the sentence, 'Young people who look for work in towns usually . ., 72 per cent perceived the job-hunting process as depressing and degrading. The following selected responses indicate the force of feeling the majority of leavers have about employment searching in towns.

... get a lot of trouble before they get work and have nowhere to spend the night. They spend it in the bushes where water passes or in rubbish pits and this results in diseases and death. 
. . . find it difficult to get work and where to sleep, what to eat, etc. And if they don't have somebody whom they know, clearly they cannot get work at all.

... walk up and down the town and some go to offices to ask for employment. Some of them when they don't get employment begin to steal and most of them are imprisoned.

... don't get a job and then they just go and sit at their homes and dig their father's farm.

Yet despite this realization of job-hunting difficulties, the majority of leavers intended to search for employment away from home. Apparently, the students' felt needs for income are so strong that they persist in what seems hopeless to many of them. To discover why students thought they needed a steady income, they were asked to complete the sentence, 'I would like to earn money so that I can ...'

TABLE IV

Students' felt needs for income*

\begin{tabular}{llc}
\hline Boys & Needs & Girls \\
\hline 4I\% & Buy land & $6 \%$ \\
3I & Help parents & 26 \\
24 & Pay siblings' school fees & 58 \\
I7 & Buy clothes & 2 I \\
8 & Marry (buy cows) &. \\
7 & Buy taxi & II \\
5 & Become cash-crop/dairy farmer &. \\
5 & Build permanent house & 6 \\
2 & Have a good life & 6 \\
2 & Apply for training &. \\
. & Build a shop & 6 \\
I & Help the nation & 6 \\
\hline
\end{tabular}

* This question was open-ended and the responses therefore total over roo per cent. The percentage refers to the proportion of the total number of respondents.

Table IV implies that students' felt needs for income strongly reflect parental attitudes towards the responsibilities of an income-earning child. Students are concerned about the welfare of their families and see the local community as the area in which to invest for their future. In addition, the felt needs for income of many girls arise from the new roles open to women in the community. Responses such as buying taxis and land, building houses and shops indicate a sense of social and economic independence.

Students view schooling as a means of obtaining a steady income to satisfy obligations to their families and invest for their future in the local community. Although they perceive that their chances of obtaining an aided Form I place and/or wage employment are slight, they persist because few viable alternatives are open to them. Yet, if alternatives for academic education were available which were tailored to meet the needs of the community and the entrepreneurial constraints facing youngsters, both students and parents would seem ready to turn their efforts in that direction. 


\section{SUMMARY}

A picture of an on-going traditional life in a rural-agricultural setting is far from the socio-economic realities of Maragoli. The community's economic life-blood is composed of a flow of labour migrants to town centres. Maragoli males exploit urban employment niches out of the necessity maintained by population density and limited land resources at home. In addition, Maragoli parents have historically looked to the school as the channel through which employment could be obtained.

Population pressure on the land, sociological changes in family organization, and the felt lack of social security in old age are among the major factors which have shaped parental attitudes towards the role of the school. Vocational training in the past was not nullified by parental preference for elitist occupations, but rather failed because it had not been tailored to fit the needs of the community and to overcome the entrepreneurial constraints facing youngsters.

Community attitudes towards education, and the actions which these attitudes provoke, place constraints upon the operation of the school which slows down the system and lowers the standard of teaching.

The community has realistic perceptions of the labour market and of opportunities for entrance into an aided secondary school. Furthermore, there appears to be alienation from the urban environment and a desire, on the part of school leavers, to work and invest in the local area. Although the community seems ready for vocational training programmes as alternatives to secondary-school entry, such programmes are difficult to find and offer no guarantee of employment. Until vocational programmes are designed which offer quality training and institutional organization to overcome the constraints upon aspiring entrepreneurs, parental pressure will keep the educational system focused upon secondary-school preparation.

There is a sociological fallacy in recognizing change in urban areas, while holding 'rural' behaviour patterns as a constant. The attitudes which parents have towards the school system are rooted in the socio-economic setting of today and are not based upon the inertia of some pre-existent traditionalism. Therefore, the adaptation of an educational system to the needs of a particular area of the country requires that those needs be carefully investigated and not assumed a priori.

\section{REFERENCES}

Anderson, J. 1968. 'Primary School-leavers in Progressive Rural Areas in Kenya', Teacher Education, viii. 3. FrIENDs' African Mrssion Annual Reports, Kaimosi, Kenya.

Heijnen, J. D. 1967. 'Results of a Job Preference Test Administered to Pupils in Std. VIII, Mwanza, Tanzania', in J. Sheffield (ed.) Education, Employment and Rural Development: Report of the Kericho (Kenya) Conference, September 25 to October 1, 1966. Nairobi : East African Publishing House.

KING, K. 1972. 'Primary Schools in Kenya: Some Critical Constraints on their Effectiveness', Discussion Paper No. 130, Institute for Development Studies, University of Nairobi.

KofF, D. 1967. 'Education and Employment: Perspectives of Kenya Primary Pupils', in J. Sheffield (ed.) Education, Employment and Rural Development: Report of the Kericho (Kenya) Conference, September 2s to October 1, 1966. Nairobi: East African Publishing House.

Moock, P. 1971. 'Special Rural Development Program Evaluation Reports on a Maize Credit Scheme'. Institute for Development Studies, University of Nairobi.

SheFFIELd, J. 1967. 'Conference Conclusions', in J. Sheffield (ed.). Education, Employment and Rural Development: Report of the Kericho (Kenya) Conference, September 2s to October 1, 1966. Nairobi : East African Publishing House.

WAGNer, G. 1956. The Bantu of North Kavirondo, vol. ii. London: Oxford University Press. 


\section{Résumé \\ PRAGMATISME ET ÉCOLE PRIMAIRE: LE CAS D'UN \\ VILLAGE NON RURAL}

Cet article analyse les besoins d'éducation d'une petite communauté du Kenya sous l'angle de l'évolution des ses modèles socio-économiques, et montre comment les attitudes envers le système scolaire ont leurs racines dans cette organisation. Les faits sont tirés d'une étude de 19 mois chez les Maragoli du Sud, dans le district de Kakamega, Province de l'Ouest. Les hommes Maragoli émigrent vers les villes en raison de la densité de la population et des ressources limitées de la terre chez eux. La pression démographique sur la terre, les changements sociologiques dans l'organisation familiale et l'insécurité de la société pour les personnes âgées sont parmi les facteurs qui ont modelé les attitudes des parents quant au rôle de l'école. Autrefois les parents comptaient sur l'école comme la voie à suivre pour obtenir un emploi. La formation professionnelle a échoué parce qu'elle n'était pas adaptée aux besoins de la communauté dont les attitudes apportent des contraintes au fonctionnement de l'école, ce qui freine le système et abaisse la qualité de l'enseignement. La communauté a une perception réaliste du marché du travail et des chances d'entrer dans une école secondaire subventionnée. Il existe aussi une aliénation venant de l'environnement urbain et ceux qui quittent l'école désirent travailler et investir dans la région. Bien que là communauté paraisse prête pour des programmes de formation professionnelle en tant qu'alternative à l'entrée dans une école secondaire, de tels programmes sont difficiles à trouver et n'offrent aucune garantie de l'emploi. Jusqu'à ce que des programmes de formation aient été établis, offrant un enseignement et une organisation de grande qualité, la pression des parents maintiendra un système d'éducation axé sur la préparation de l'école secondaire. Les attitudes des parents envers le système scolaire sont fondées sur l'organisation socio-économique actuelle et non sur la tradition. Par conséquent, l'adaptation d'un système d'éducation aux besoins d'une région particulière de ce pays demande une analyse préalable approfondie de ceux-ci et non une supposition a priori. 


\section{CRED Reprint Series}

No. 35. "An Evaluation of Short-Term Forecasts of Coffee and Cocoa" by J. Kimball Dietrich and Alfredo D. Gutierrez. (American Journal of Agricultural Economics, Vol. 55, No. 1, February 1973, pp. 93-99)

No. 36. "The Birth of a Bill Market" by Richard C. Porter (Journal of Development Studies, April 1973, pp. 439-450)

No. 37. "Pragmatism and the Primary School: The Case of a NonRural Village" by Joyce L. Moock. (Africa, 1973, pp. 302-316) 
